\title{
Editorial
}

\section{President Clinton's Earnings Stripping Proposal}

\author{
Toshiaki Katsushima, Deloitte Touche Tohmatsu, Tokyo
}

In 1989, the US Congress passed the so-called 'earnings stripping' legislation which prevents a foreign owned US company from currently deducting interest paid to a related foreign company if: (i) the subsidiary's debt to equity ratio is greater than 1.5-to-1; (ii) the interest paid by the subsidiary is subject to a reduced treaty of rate of withholding; and (iii) the subsidiary's interest expense exceeds 50 per cent of its adjusted taxable income. Congress instructed the Internal Revenue Service (IRS) to write regulations applying these rules to related-party guaranteed loans when those loans were used as a device to avoid the general earnings stripping provisions. The IRS's rules were not to apply to guarantees issued in the ordinary course of business, and were only to be prospective.

The Clinton Administration has proposed enhanced earnings stripping rules which appear to unfairly restrict and increase the cost of borrowing for foreign owned US companies. The Administration's proposal would apply the earnings stripping rules to all loans-including loans from US banks - in which a related party provides any assurance of repayment to the lender, whether or not legally enforceable. Contrary to normal effective date provisions, the Administration's proposal for guaranteed loans covers previously negotiated loans. Furthermore, the Administration would apply the general earnings stripping rules retroactively to loans 'grandfathered' under the original legislation.

Analyzing the Administration's proposal from the standpoint of Japanese companies which have invested in the United States, the proposal seems to be an unwarranted extension of the earnings stripping provisions. The original earnings stripping legislation was enacted to prevent a single economic group from avoiding US tax by paying a substantial amount of tax-deductible interest to itself when the related recipient was fully or partially tax exempt. If a US subsidiary borrows from an unrelated lender with a foreign parent guarantee, the lender, not the foreign parent company, receives the income and the economic benefit of the interest.

Even if the loan frees up other funds of the foreign company, the relationship is fundamentally and economically different from a related party loan, because the US subsidiary's earnings used to pay the interest are leaving the group. Therefore, the interest paid on a guaranteed loan is not 'stripped' or received by the group on a tax-favored basis.

It is somewhat ironic that the proposal will make it more difficult for US banks to compete with foreign banks on loans to foreign controlled US subsidiaries. It seems quite logical to assume that, if the proposals are enacted, foreign controlled US subsidiaries will attempt to restructure their finances by borrowing without a guarantee or other form of assurance. Foreign lenders who have long-established banking relationships with a foreign company will be more able to lend to the US subsidiary without any assurance because of their greater knowledge for the group's business and worldwide financial situation. From the Japan perspective, it appears likely that US banks will not be able to compete with foreign banks in restructuring the highest quality pool of business which will be effected by the Administration's proposal.

Oddly enough, the proposal also carries an unanticipated cost in terms of reduced job opportunities for Americans by making it difficult for small and medium foreign-controlled US subsidiaries to start or expand US operations. These are, of course, the companies most likely to need foreign parent company guarantees. By making it more difficult and costly for this type of firm to raise the capital necessary to start or expand their operations in the United States, the proposal will reduce their ability to create new US jobs for Americans.

It is also difficult to see the benefit in the Administration's proposals when looking at it from the standpoint of the US Treasury. The legislation seems likely to reduce the taxes paid by many foreign controlled US subsidiaries by increasing their cost of borrowing. If these 
companies no longer seek foreign parent guarantees, they will be required to pay additional, tax-deductible interest to third party lenders.

Notwithstanding these drawbacks, at this time it appears that the legislation stands a reasonable chance of being enacted. In this case, one would recommend that the legislation be modified as follows:

1. Do not apply the enhanced rules to loans from US banks or similar taxable lenders. Interest paid to a US bank and similar lenders is fully subject to the US tax. There is no reason to apply the earnings stripping rules to these loans since long standing US tax principles prevent any potential abuse (See: Plantation Patterns, Inc. v. Commissioner, 462 F. 2d 712 (5th Cir), cert. denied, 409 US 176 (1972)).

2. Increase the 1.5-to-1 debt-to equity ratio. Treating guaranteed loans as 'earnings stripping' loans would impose limits in many situation that are not abusive, by combining an expansive concept of related-party loan with an unduly restrictive debt-to-equity threshold. Historically, the US Treasury and tax practitioners have considered debt-to-equity ratios substantially in excess of 1.5-to-1 to be reasonable. Furthermore, these higher ratios have been computed using the fair market value of assets, rather than the generally lower tax basis that is used in the current earnings stripping rules.

The current 1.5-to-1 debt-to-equity ratio is based on an understanding that the median debt-to-equity ratio for US publicly traded corporation is less than 1.5-to-1. It is not clear that this ratio is reflective of US privately held companies which do not have access to the capital markets. By raising the debt-to-equity threshold, Congress would spare many non-abusive taxpayers from being unfairly covered by the earnings stripping limitations.

3. Apply the new rules only to legally enforceable guarantees. Treating unenforceable assurances of payment like legal guarantees would create administrative issues and significant uncertainty in the business community about how much assurance is 'too much'.

4. The proposed legislation should be applied only to debt incurred after its passage. The original earnings stripping legislation applied only to obligations issued on or after the introduction of the legislation. Congress also intended the extension of the earnings stripping rules to guaranteed debt to be prospective only.

Expanding the earnings stripping rules to cover guaranteed debt and previously grandfathered debt on a retroactive basis departs from past legislative practice and stated Congressional intent. Many taxpayers justifiably relied upon the effective dates and what was then Congressional intent to arrange their financial affairs. Tax legislation traditionally is passed on a prospective basis, so that taxpayers may arrange their affairs without suffering unexpected punitive consequences from relying on the law that existed prior to change. 